\title{
Pola Irama Keroncong Progresif pada Komposisi Kidung Panyuwun
}

\author{
Singgih Sanjaya ${ }^{1}$ dan Irvan Rizki Fauzi \\ Prodi D4 Penyajian Musik, Fakultas Seni Pertunjukan, Institut Seni Indonesia Yogyakarta
}

\begin{abstract}
The Rhythm Pattern of Progressive Keroncong in Kidung Panyuwun Composition. The research on the rhythm pattern of progressive keroncong creates a progressive keroncong rhythm pattern and creates the composition. Keroncong music is one of the music genres in Indonesia, which is hybrid music from Javanese karawitan, 'pop' music and Western diatonic music. Keroncong music consists of vocals, ukulele (derived from Hawai'i), 'cak', flute, violin, cello, and contrabass. From the 1950s to the present day, the rhythm pattern of keroncong is slightly flourished, so it needs to be developed. There are several rhythm patterns in keroncong music, but the rhythm pattern of 'engkel' and 'dobel' are often played. This study aims to create a progressive keroncong rhythm pattern so that keroncong music is more exciting and expected to have more fans. This study uses descriptive and experimental analytical methods with the following steps, as followings: First, looking at audio recordings, transcribing, analyzing, and deducing; second, analyzing the rhythm patterns on multiple references; third, recording (audio-video) the rhythm pattern of 'pakem'; fourth, doing the exploration of progressive rhythm patterns; and fifth, recording the rhythm pattern of progressive keroncong. This research produced several creations of rhythm patterns and several formulations, namely: (1) The creation of vertical rhythm pattern of progressive keroncong (solo of one instrument, solo of two instruments, solo of three instruments); (2) The creation of horizontal rhythm pattern of progressive keroncong (two-bars patterns and four-bars patterns).
\end{abstract}

Keywords: rhythm pattern; keroncong; progressive, Kidung Panyuwun

\begin{abstract}
ABSTRAK
Pola irama keroncong progresif pada komposisi Kidung Panyuwun menciptakan pola irama keroncong progresif dan menciptakan komposisi. Musik keroncong adalah salah satu genre musik yang ada di Indonesia merupakan musik hibrid dari karawitan Jawa, musik 'pop' dan musik diatonis Barat. Musik keroncong terdiri dari vokal, ukulele (berasal dari Hawai'i), 'cak', flute, biola, cello, dan contrabass. Sejak tahun 1950-an sampai hari ini, pola irama keroncong sedikit perkembangannya sehingga perlu dikembangkan. Ada beberapa pola irama dalam musik keroncong tetapi yang sering dimainkan hanya pola irama 'engkel' dan 'dobel'. Tujuan penelitian ini untuk menciptakan pola irama keroncong progresif sehingga musik keroncong lebih menarik dan diharapkan lebih banyak penggemarnya. Penelitian ini menggunakan metode analitik deskriptif dan eksperimental dengan lankah-langkah sebagai berikut. Pertama mencermati rekaman audio, mentranskrip, menganalisis, dan menyimpulkan; kedua menganalisis pola irama pada beberapa referensi; ketiga merekam (audio-video) pola irama 'pakem'; keempat eksplorasi pola irama progresif; kelima merekam pola irama keroncong progresif. Penelitian ini menghasilkan beberapa ciptaan pola irama dan beberapa formulasi, yaitu: (1) Penciptaan pola irama keroncong progresif vertikal (solo satu instrumen, solo dua instrumen, solo tiga instrumen); (2) Penciptaan pola irama keroncong progresif horizontal (pola dua birama dan pola empat birama).
\end{abstract}

Kata kunci: pola irama; keroncong; progresif; Kidung Panyuwun

\footnotetext{
Alamat korespondensi: Prodi D4 Penyajian Musik, Fakultas Seni Pertunjukan, Institut Seni Indonesia Yogyakarta, Jalan Parangtritis Km. 6,5 Sewon, Bantul, Yogyakarta. E-mail: singgihsanjaya.sspro@gmail.com; HP.: 087738738762.
} 


\section{Pendahuluan}

Hubungan manusia dengan musik sangat erat sekali. Hampir semua manusia setiap hari mendengar, mendengarkan dan merasakan musik. Manusia akan menyatu dengan budaya musiknya masing-masing. Tiap-tiap suku bangsa di dunia ini mempunyai budaya musik sendiri-sendiri.

Hal ini juga terjadi pada suku-suku bangsa di Indonesia. Orang Minangkabau dengan musik Talempong, orang Dayak dengan musik Dayak, orang Bugis dengan musik Makassar, orang Jawa (Jawa Tengah dan D.I.Y) dengan musik Gamelan. Sebagian orang Jawa menyukai musik keroncong.

Musik keroncong merupakan musik hibrid dari beberapa genre musik, yaitu karawitan Jawa (Jawa Tengah dan Yogyakarta), musik 'pop' (musik diatonis Barat), dan musik orkestra Barat. Salah satu referensi juga menyebut bahwa musik keroncong merupakan musik percampuran karakteristik antara elemen musik luar negeri dengan rasa lokal (Bramantyo, 2018).

Musik keroncong popular pada tahun 1970 an dan 1980-an, tetapi setelah masa tersebut kepopuleran musik keroncong menurun (Alfian, 2013). Musik keroncong diyakini berasal dari Portugis (Ganap, 2006). Sejak tahun 1940-an, musik keroncong sudah menggunakan susunan instrumen yang 'baku' atau 'pakem'. Formasi 'pakem' ini terdiri dari vokal, biola, flute, cak, cuk (ukulele atau keroncong), cello, gitar, dan bass. Formasi ini oleh sebagian besar musisi keroncong disebut 'formasi asli' (Ramadhani \& Rachman, 2019). Gamelan Jawa sangat memengaruhi gaya bernyanyi dan gaya permainan seluruh instrumen, kecuali instrumen bass. Musik 'pop' Barat memengaruhi pada harmoni, bentuk lagu, dan pola permainan bass secara relatif.

Pada perkembangannya musik keroncong menemukan beberapa permainan pola irama yang telah mapan, yaitu pola irama: (1) Engkel; (2) Dobel; (3) Kothek'an; (4) 'Jakarta-nan'; (5) Tanbu-liong. Dari kelima pola irama ini, ada dua pola irama yang biasa digunakan, yaitu pola irama engkel dan dobel. Pola irama kothek'an dan 'jakarta-nan' relatif jarang dimainkan, sedangkan pola irama 'tanbuliong' lebih jarang dimainkan. Pola irama tersebut ada kemiripannya dengan pola irama Orkes Keroncong Irama Jakarta, yaitu dobel engkel, dobel balik, format dan gaya lama (Supiarza et al., 2019).

Pengamatan penulis, bahwa salah satu sebab musik keroncong tidak banyak dinikmati itu karena pola irama tersebut dianggap monoton atau membosankan bagi sebagian besar masyarakat. Setiap aranjer atau komponis mempunyai cara masing-masing untuk berusaha supaya keroncong lebih menarik. Hal ini juga dilakukan oleh grup keroncong Tresnawara dengan penggarapan yang lebih dinamis (Widyanta, 2017). Di sisi lain dikatakan bahwa pola irama keroncong tersebut merupakan 'kearifan lokal'. Berdasarkan permasalahan di atas, penelitian ini akan menciptakan 'pola irama keroncong progresif' yang berarti pola irama yang 'dikembangkan' supaya menarik dan diminati oleh banyak masyarakat.

Melihat perkembangan musik keroncong, khususnya pada pola iramanya, dapat dikatakan bahwa perkembangan pola irama keroncong sangat lamban atau tidak berkembang. Jika membandingkan perkembangan musik keroncong dengan musik jazz, perkembangan musik jazz jauh lebih pesat. Hal ini dapat dilihat pada sejarah perkembangannya. Genre blues (pertengahan abad ke-18), ragtime (tahun 1890-an), dixie (1900-an), swing (1930 s.d. 1940-an), bebop (1950-an), cool jazz (1960-an), modern/free jazz (1960 s.d. 1970-an), fusion (1970 s.d. 1980-an). Berdasarkan dua masalah tersebut, yaitu musik keroncong kurang digemari masyarakat dan pola irama musik keroncong tidak atau sangat sedikit perkembangannya sejak tahun 1950-an sampai hari ini, maka penciptaan pola irama musik keroncong yang inovatif mendesak untuk dilakukan.

Penciptaan pola irama keroncong progresif ini diterpkan pada komposisi penulis yang berjudul Kidung Panyuwun. Instrumentasi komposisi tersebut untuk vokal wanita solo, paduan suara, keroncong dan orkestra. Penciptaan komposisi Kidung Panyuwun terinspirasi oleh pandemi Covid 19. Pandemi tersebut merupakan sebuah fenomena dunia yang membunuh banyak orang dan merusak tatanan ekonomi yang akhirnya memporakporandakan semua tatanan kehidupan di planet bumi ini. Berita ini dikabarkan dari Wuhan 
(salah satu daerah di China) bahwa pandemi ini dimulai sejak Desember 2019. Pada tanggal 12 Januari 2020, World Health Organization (WHO) menyatakan bahwa ini sebuah virus baru yang dinamakan Corona Covid 19 (Sun et al., 2020).

\section{Metode Penelitian}

Salah satu referensi metode yang digunakan dalam penelitian seni pertunjukan adalah buku yang berjudul Metodologi Penelitian Seni Pertunjukan dan Seni Rupa (R.M Soedarsono, 2000). Penelitian ini menggunakan metode analitik deskriptif dan eksperimental. Proses penelitian ini dengan langkah-langkah sebagai berikut, 1) mencermati rekaman audio, mentranskrip, menganalisis, dan menyimpulkan; 2) menganalisis pola irama pada referensi; 3) merekam (audio-video) pola irama 'pakem'; 4) eksplorasi pola irama progresif; 5) merekam pola irama keroncong progresif. Beberapa roses penciptaan ini ada kemiripannya dengan proses penciptaan Komposisi karawitan yang berjudul Pyang Pyung (Suneko, 2017).

Penulis merasakan bahwa pengalaman lebih dari empat puluh tahun dari saat awal 'merangkak' belajar flute keroncong dan akhirnya selain bermain flute/ewi terus menciptakan komposisi concerto. Tahun 2008 penulis menciptakan karya concerto yang berjudul Clarinet Concerto with Keroncong and Orchestra. Karya ini dapat dilihat pada kanal Youtube. Bagian satu: Singgih Sanjaya Clarinet Concerto $1^{\text {st }}$ LKO 2008, link: https://youtu.be/ ZYZRXO-7VVc. Bagian dua: Singgih Sanjaya Clarinet Concerto $2^{\text {nd }}$ LKO 2008, link: https:// youtu.be/ZYZRXO-7VVc. Penggarapan komposisi ini menggunakan teori komposisi musik diatonis Barat yang mengambil idiom musik karawitan Jawa. Model penciptaan ini juga seperti penggarapan komposisi untuk piano yang berjudul Drupadi karya Ananda Sukarlan (Kristiana, 2016).

Penulis merasa bahwa eksplorasi penggarapan pola iramanya tidak maksimal akhirnya penulis mengadaptasi komposisi tersebut untuk Oboe solo yang berjudul Oboe Concerto with Keroncong and Orchestra yang dimainkan pada bulan September 2012 pada acara Solo Keroncong Fesival, sebuah acara tahunan di kota Surakarta.
Penggarapan Oboe Concerto with Keroncongand Orchestra salah satunya memfokuskan penggarapan dan pelatihan 'pola irama'nya. Karya tersebut digarap pada tahun 2012 selain mengadaptasi inrumen 'solo'nya dari clarinet diadaptasi ke oboe. Saat itu penulis merasa menghasilkan kreasi musikal yang cukup signifikan dan sadar bahwa eksplorasi tersebut masih terus harus dilakukan. Beberapa teknik panggarapan yang dihasilkan di antaranya sebagai berikut. Eksperimentasi pola irama engkel dengan hanya menggunakan 'satu nada' saja. Unisono untuk instrumen keroncong (cak, cuk, cello, gitar dan bass) dengan rajutan melodi atonal, seperti rajutan dua belas nada (England $\&$ Dallin, 1958). Pengalaman penggarapan karya komposisi ini akhirnya penulis mempresentasikan pada acara International Conference for Asia Pasific Art Studies (ICAPAS). Akhirnya tulisan tersebut diterbitkan di jurnal Pascasarjana ISI Yogyakarta International Jurnal of Creative of Arts Studies (IJCAS). yang berjudul New Composition Concept for Keroncong Music in the Oboe Concert with Keroncong and Orchestra (Sanjaya, 2018). Karya ini dapat dilihat pada kanal Youtube (versi rekaman): Singgih Sanjaya Oboe Concerto $1^{\text {st }}$ LKO 2012. Link: https://youtu.be/3UldqAxTMz0 dan Singgih Sanjaya Oboe Concerto 2nd LKO 2012. Link: https://youtu.be/TiEvwcJB2_U. Versi live: Singgih Sanjaya Concerto Oboe bag 1, link: https://youtu. be/0OGq0GTAjro dan Singgih Sanjaya Concerto Oboe bag 2, link: https://youtu.be/1HOHL2iB_ BI.

Mencermati sejarah perkembangan musik keroncong merupakan hal dasar yang penting untuk dilakukan karena hal ini menjadi salah satu pijakan dalam mengembangkan musik keroncong. Mendengarkan, "merasakan", mentranskrip, menganalisis dan menyimpulkan yang dimulai dari gaya tradisi sampai pada perkembangannya saat ini menjadi hal yang harus dilakukan. Dengan proses tersebut penulis dapat merasakan estitika musikal musik keroncong sehingga penulis dapat menyimpulkan bahwa 'kearifan' musik keroncong terletak pada gaya permainan hampir semua instrumen keroncong, yaitu cak, cuk, cello, gitar dan bass. Hal ini sejalan dengan tulisan yang berjudul Transformasi Konfrontatif Komposisi 
Gamelan Baru: Revitalisasi Penciptaan Inovatif dan peran Vital Perguruan Tinggi Seni. Salah satu hal yang sependapat dengan penulis adalah bahwa untuk mengembangkan garapan sebuah seni modern mutlak diperlukan penguasaan seni tradisi secara matang. "Implikasi kesadaran yang diharapakan terbentuk adalah totalitas keyakinan bahwa inovasi kreatif bukanlah ajang pelarian karena ketida-kmampuan bermain tradisi dengan baik dengan menjadikan gamelan atau musik Barat sebagai objek eksploitasi serta materi kolaborasi materialistik yang dangkal' (Jayantoro, 2019).

\section{Pola Irama Engkel dan Dobel}

Setelah mencermati rekaman audio pada beberapa grup kemudian ditranskrip ke dalam partitur dengan instrumen tasi gitar, cak, cuk (ukulele), cello dan bass.

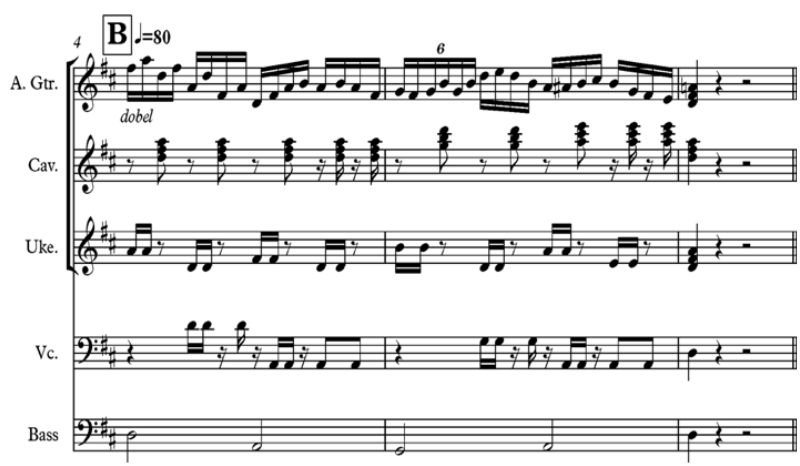

Notasi 1: Pola irama keroncong 'Engkel'.

Dalam partitur di atas, gitar bermain improvisasi secara chordal dan lick dengan notasi 1/16-an. Cak bermain akor dengan not 1/8 pada ketukan 1, 2, dan 3 bermain sinkup. Sedangkan pada ketukan empat, bermain sinkup 1/16-an. Instrumen ukulele pada ketukan satu bermain chordal lalu dilanjutkan ketukan dua bermain trimolo dan pola dua ketukan ini juga dimainkan pada ketukan ketiga dan keempat. Instrumen cello bermain seperti (imitasi) permainan kendang gamelan Jawa yang telah dimodifikasi sedemikian rupa. Salah satu referensi juga menyebut bahwa permainan cello mirip kendang Jawa (Prakosa $\&$ Haryono, 2012). Permianan cello terdapat unsur bermain secara improvisasi. Instrumen bass, pada prinsipnya setiap birama bermain dua nada yang bernilai $1 \frac{2}{2}$. Pola ini kiranya seperti permainan bass pada musik pop yang berirama slow beat.
Perpaduan gaya masing-masing instrumen di atas merupakan 'ruh' atau 'jati diri' musik keroncong. Dapat dikatakan atau disimpulkan bahwa permainan ansambel tersebut merupakan ciri khas musik keroncong. Selanjutnya dibahas gaya permainan pola irama dobel.

Pola irama keroncong dobel merupakan imitasi dari pola irama 'rangkep' (rangkap). Nuansa dari permainan pola irama dobel ini terasa dinamis seperti dobel temponya, tetapi sesungguhnya tempo tiap ketukan justru lebih sedikit lambat. Tradisi permainan pola rangkap juga terdapat dalam musik jazz. Kiranya variasi permainan pola irama engkel ke dobel bermaksud untuk membawa nuansa lebih dinamis sehingga tidak membosankan.

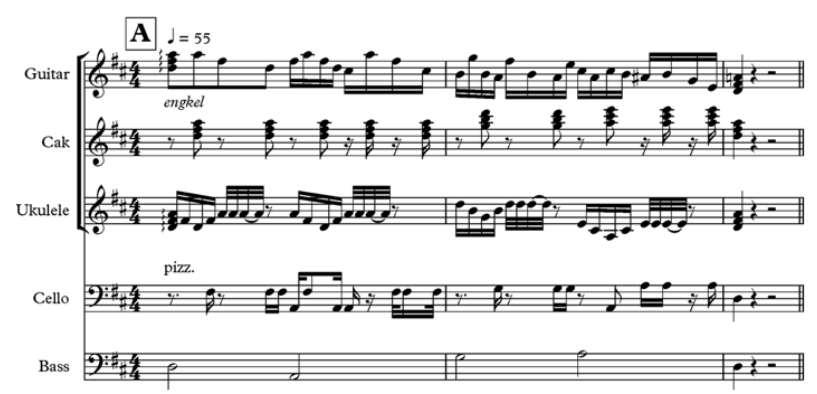

Notasi 2: Pola irama keroncong 'Dobel'.

Dalam partitur di atas, gitar bermain improvisasi secara chordal dan lick dengan notasi 1/32-an, yang terkadang bermain dengan 'sektul' seperti pada ketukan pertama birama dua pada partitur di atas Cak bermain akor dengan not 1/8 pada ketukan satu, dua, dan tiga bermain sinkup. Sedangkan pada ketukan empat, bermain sinkup 1/16-an. Pada prinsipnya serupa dengan pola irama engkel. Instrumen ukulele pada ketukan satu, dua, tiga, dan empat bermain notasi 1/16-an dan pada 1/16-an ketiga dan keempat istirahat.

Instrumen cello bermain seperti (imitasi) permainan kendang gamelan Jawa yang telah dimodifikasi sedemikian rupa. Permainan cello terdapat unsur bermain secara improvisasi. Instrumen bass, pada prinsipnya setiap birama bermain dua nada yang bernilai $1 / 2$. Pola ini kiranya seperti permainan bass pada musik pop yang berirama slow beat, seperti halnya pada pola irama engkel. Selanjutnya dibahas penggarapan pola irama progresif yang diterapkan pada komposisi Kidung Panyuwun. 


\section{Pembahasan Lagu Kidung Panyuwun}

Penciptaan lagu Kidung Panyuwun mendapat inspirasi dari wabah COVID-19 yang melanda di dunia dari bulan Desember 2019 dan menyebar ke Indonesia yang diawali pada sekitar bulan Maret 2020. Wabah tersebut merupakan pandemi dunia, yaitu sebuah wabah yang dahsyat menyebabkan banyak orang meninggal dan juga berdampak pada ekonomi, sosial, dan politik. Peristiwa tersebut, peneliti tergerak untuk menciptakan sebuah lagu.

Konsep penciptaan lagu diawali dengan plotplot penciptaan lirik yang terdiri dari 3 bait. Bait pertama menceritakan keadaan bumi Indonesia yang (relatif) tenang dan aman. Pada bait kedua melukiskan dimulainya wabah COVID-19 dan pada bait ketiga yang berisi tentang ajakan untuk berdoa semoga wabah ini segera berlalu.

Lirik:

Angin smilir reruntungan mega

Wus sumunar Hyang baskara

Edi peni kahananing donya

Nugrahaning Maha Kuasa

Sengkala tumeka

Jan ma'keh lelara

Nemahi sengsara

Tan ora kanyono

Gusti Panguasa bawana

Prabaning Hyang sasmita

Paring panyendhu manungsa

Awujud prahara

Panyuwun kawula Gusti

Mugi Paduka pungkasi

Mendhung panelangsa ati

Nyuwun pangaksami

Arti:

Angin semilir Mega berarak

Telah bersinar sang mentari

Sungguh indah keadaan dunia

Anugerah yang Maha Kuasa

Rintangan kehidupan datang

Manusia banyak yang sakit

Menemui kesengsaraan

Yang tidak pernah terduga
Tuhan Penguasa Bumi

Sang pemberi isyarat

Memberikan peringatan pada manusia

Yang berwujud bencana

Permohonanku Tuhan

Semoga Engkau akhiri

Mendung nestapa di hati

Mohon ampunan

Konsep penciptaan melodi berdasarkan pada gagasan lirik yang terdiri dari tiga mood (suasana) seperti pada lirik di atas. Penggarapan melodi berdasarkan pada interpretasi lirik (Singgih Sanjaya, 2013).

Voice
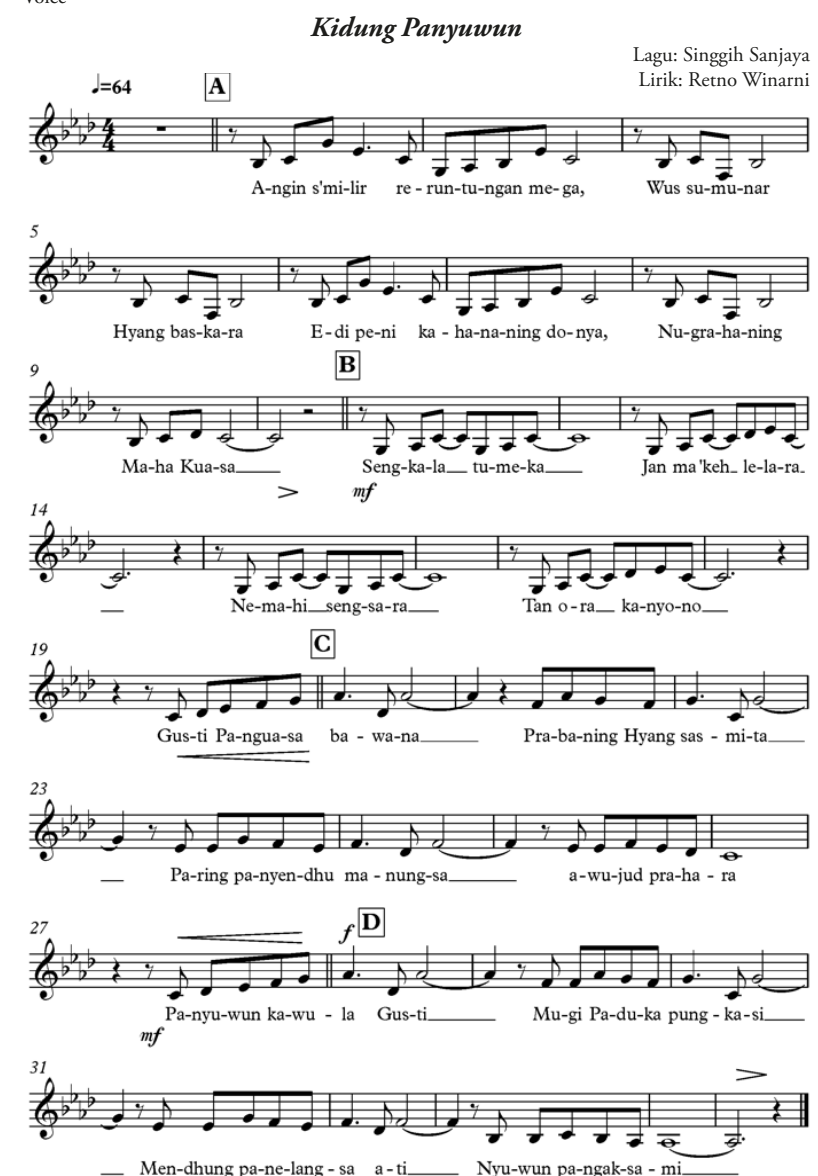

Notasi 3: Lagu Kidung Panyuwun.

Pada prinsipnya, melodi lagu Kidung Panyuwun menggunakan tangga nada diatonis. Pada bait pertama disusun suasana melodi mayor yang menggambarkan suasana tentram dan aman (Notasi 4).

Pada bait kedua, melodi menggunakan tangga nada pelog yang berkesan minor yang menggambarkan saat datangnya COVID-19 (Notasi 5). 

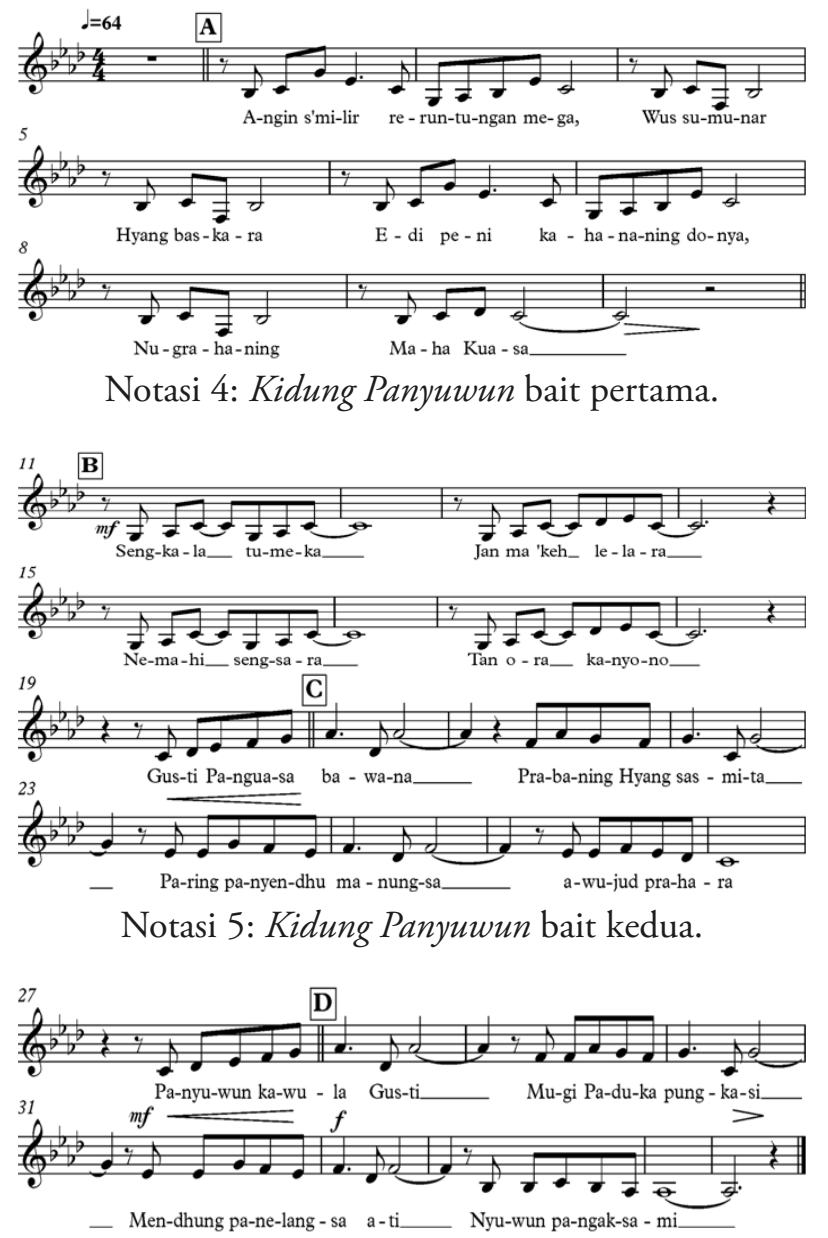

Notasi 6: Kidung Panyuwun bait ketiga (bagian akhir).

Pada bait ketiga, menggunakan tangga nada mayor yang mengekspresikan kata panyuwun yang berarti sebuah doa untuk keselamatan.

\section{Pembahasan Komposisi Kidung Panyuwun}

Komposisi ini berekspresi andante cantabile. Andante berarti mempunyai $\boldsymbol{d}=\mathbf{6 4}$ tempo relatif sedang, kira-kira secepat orang berjalan, sedangkan cantabile berarti "menyanyi" yang berarti terdapat suasana merdu. Pada awal komposisi ini (pada partitur) juga tertulis yang berarti bahwa notasi seharga seperempat mempunyai kecepatan 64 ketukan/menit. Dalam istilah musik disebut 64/bpm (beat per minute). Komposisi ini menggunakan sukat $4 / 4$ dalam kunci 4 mol. Kunci tersebut berdasarkan ambitus penyanyi vokal solo, khususnya pada lagu ini.

Komposisi ini diawali oleh introduksi sebanyak dua bar yang mengambil melodi dari motif awal lagu Kidung Panyuwun. Setelah itu, masuk pada lagu Kidung Panyuwun yang memerankan vokal solo wanita sebagai lied (huruf A) sebanyak sembilan birama. Huruf A menceritakan tentang keadaan dunia yang relatif aman dan tentram. Konsep penggarapan pada bait pertama, intrumentasi digarap secara "tipis" yang terdiri dari vokal solo utama yang pada awalnya bersamaan dengan blocking piano secara ringan (leggiero), juga cello yang disusul viola, violin 1, kemudian seksi gesek bermain semua pada tiga birama terakhir.

Huruf B menceritakan datangnya wabah COVID-19 sebanyak delapan bar. Permainan blocking piano tetap sama seperti pada huruf A yang didasari dengan nada cello yang dimainkan secara pizzicato. Pada bagian B ini, dihadirkan pola irama keroncong yang baru yang akan dibahas pada pembahasan inovasi keroncong. String secara bersama-sama masuk pada empat sebelum huruf C sebagai pengantar ke bagian $\mathrm{C}$ yang merupakan refren dari lagu ini. Bagian B menggunakan tangga nada minor sebagai ekspresi dari suasana datangnya wabah yang menakutkan.

Huruf C (berjumlah delapan birama) merupakan hal yang penting dari lagu ini (klimaks). Instrumentasi digarap lebih penuh dengan menghadirkan instrument seksi gesek, bass elektrik, drum set, dan seksi keroncong yang terdiri dari cak, cuk, cello, dan gitar akustik. Pada bagian akhir ini diperkuat lagi dengan paduan suara menggunakan nada panjang sebagai pendukung untuk menaikkan suasana klimaks.

Huruf D (berjumlah delapan birama) merupakan klimaks dari lagu Kidung Panyuwun. Bagian ini merupakan ungkapan doa yang memohon kepada Tuhan untuk mengakhiri wabah COVID-19. Suasana pada huruf D ini dikonsep secara sakral dengan ekspresi grandioso (besar) dengan orkestrasi digarap hampir penuh.

Huruf E (berjumlah empat birama) merupakan interlude awal yang digarap dengan solo piano saja. Konsep penggarapan ini adalah membuat suasana kontras dari klimaks secara tiba-tiba menjadi "sepi". Solo piano disusul string pada birama ketiga ketukan dua setengah sebagai jembatan menuju huruf $\mathrm{D}$.

Huruf $\mathrm{F}$ merupakan ulangan suasana huruf E. Bagian terpenting dari huruf $F$ ini adalah pe- 
nonjolan pola irama keroncong inovatif. Pada bagian ini yang bermain adalah seksi keroncong yang merupakan garapan baru yang dibahas pada bagian selanjutnya. Bagian F ini diakhiri oleh permainan seksi gesek: contra bass bermain nada panjang, cello memainkan tema motif melodi awal dengan penggarapan augmentasi (pelebaran nada), alto memainkan tema motif melodi awal yang disambung dengan nada panjang kemudian disusul permainan violin 2 yang dimulai pada ketukan satu setengah yang memainkan nada-nada seperti viola naik satu oktaf yang juga diakhiri dengan nada panjang. Kemudian disusul oleh violin 1 yang mulai bermain pada ketukan dua setengah yang memainkan sekuen naik interval empat dari violin 2 .

Huruf G (berjumlah lima birama) pada dasarnya merupakan pengulangan dari bagian sebelumnya dengan beberapa pengembangan, yaitu pada bagian ini nada dasar yang semula As dinaikkan menjadi C. Hal ini bertujuan untuk menaikkan mood sehingga secara audio tidak membosankan. Hal penting dari bagian ini adalah soli (solo yang dimainkan bersama) melodi seksi gesek merupakan pengembangan dari motif tema awal lagu Kidung Panyuwun yang dimainkan oleh violin 1, violin 2, dan viola, kemudian disusul instrument cello satu bar yang diakhiri dengan nada panjang yang memainkan nada tonika (C). Nada panjang tersebut diperkuat dengan contra bass yang bermain satu oktaf di bawahnya.

Huruf $\mathrm{H}$ kembali pada bait kedua (huruf B). Pada prinsipnya huruf H, I, dan J merupakan pengulangan dari huruf $\mathrm{B}, \mathrm{C}$, dan $\mathrm{D}$ yang dimodifikasi. Huruf $\mathrm{C}$ merupakan bagian akhir dari komposisi ini sehingga secara harmoni digarap dengan modulasi menaikkan satu tonika dari As ke Bes. Secara instrumentasi digarap dengan pengembangan yang berarti lebih penuh, khususnya pada huruf J semua instrumen dimainkan.

\section{Penerapan Pola Irama Keroncong Progresive}

\section{a. Penerapan Keroncong Inovatif Dimulai pada Komposisi Kidung Panyuwun di Huruf B}

Konsep pola irama keroncong inovatif $1 \mathrm{ini}$ menonjolkan permainan gitar filosof "banyumili”. Istilah "banyumili” berarti "banyu" adalah air dan "mili" adalah mengalir. Istilah "banyumili” pada konteks ini berarti air yang mengalir secara alamiah. Jadi permainan instrumen gitar didasari oleh filosofi Jawa tersebut.

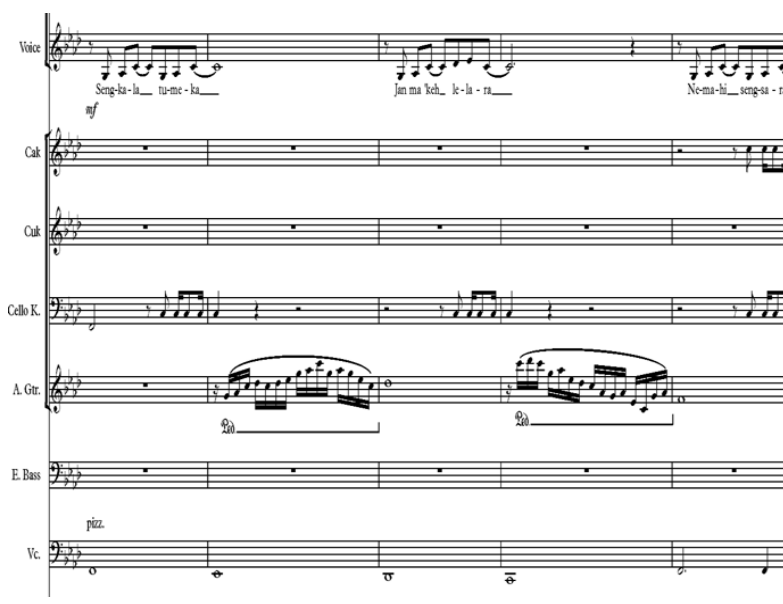

Notasi 7: Pola irama keroncong inovatif 1.

Melihat tekstur pada partitur di atas (Notasi 7), terlihat secara jelas bahwa garapan gitar dengan gaya "banyumili" di atas merupakan dialog antara vokal solo dan permainan gitar "banyumili". Peneliti mengonsep penonjolan pada instrumen gitar "banyumili" supaya terdengar jelas tanpa terganggu oleh instrumen lain. Untuk mencapai hal tersebut orkestrasi bagian ini dibuat minim. Instrumen yang bermain adalah vokal solo berdialog dengan permainan gitar yang diberi sedikit isian oleh instrumen cello kendang, dimaksudkan untuk memberi umpan untuk masuknya instrumen gitar. Pada bagian ini instrumen cuk sengaja dikonsep untuk tidak bermain sama sekali. Instrumen cak bermain sangat minim pada birama kelima ketukan dua setengah dan itupun bermain unison dengan isntrumen cello kendang. Untuk menjaga harmoni, instrumen cello bermain pada setiap pukulan pertama not utuh setiap birama dengan teknik pizzicato. Dengan garapan tekstur ini, vokal dan gitar diposisikan sebagai pemeran utama.

b. Penerapan Keroncong Inovatif yang Kedua Dimulai pada Komposisi Kidung Panyuwun di Huruf C

Konsep garapan pola irama pada bagian ini berdasarkan permainan instrumen drum set. Penulis menambah instrumentasi pada garapan bagian ini dan setelahnya. Instrumen 
drum berfungsi sebagai 'penguat beat' karena penggarapan bagian ini ada kemiripannya dengan genre musik pop atau 'fusion' (campuran gaya pop, jazz, rock). Penambahan instrumentasi khususnya drum juga dilakukan oleh grup keroncong dari Sawahlunto (Hendry, 2013)

Pola irama drum ini dapat dilihat pada birama awal huruf C. Pola bagian ini dibentuk setiap satu birama, jadi instrumen drum mengulangi pola permainan setiap satu birama sehingga birama-birama berikutnya ditulis dengan tanda repeat.

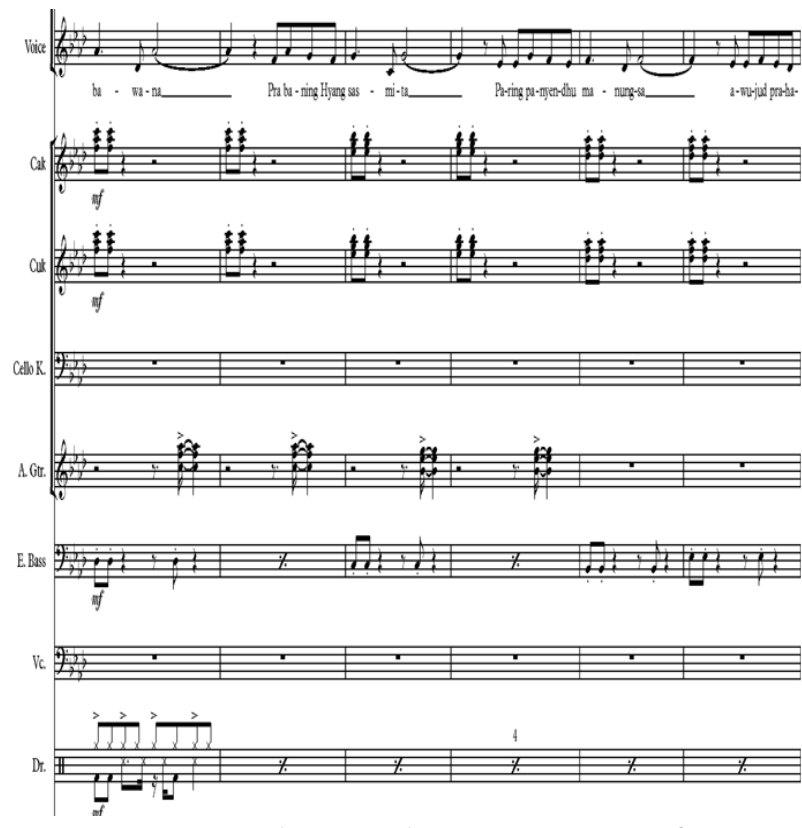

Notasi 8: Pola irama keroncong inovatif 2.

Penggarapan instrumen cak, cuk, dan bas gitar sebagai penguat pukulan kick drum set pada dua nada awal, yaitu nada 1/8. Jadi setiap biramanya, instrumen cak, cuk, dan bass gitar hanya bermain dua nada. Sedangkan instrumen gitar memberi aksen pada ketukan sinkup setiap biramanya yang menggantung pada akhir ketukan 4 seperenambelasan (Notasi 8). Instrumen cello sama sekali tidak bermain. Bagian ini diakhiri dengan permainan unison cak, cuk, cello kendang, gitar, dan bass.

c. Penerapan Keroncong Inovatif yang Ketiga Dimulai pada Komposisi Kidung Panyuwun di Huruf D

Pola irama inovatif yang ketiga ini pada dasarnya seperti pola irama inovatif yang kedua dengan modifikasi pada permainan instrumen cuk, gitar akustik, dan drum. Pada prinsipnya, modifikasi tersebut berfungsi sebagai penguat permainan instrumen drum.

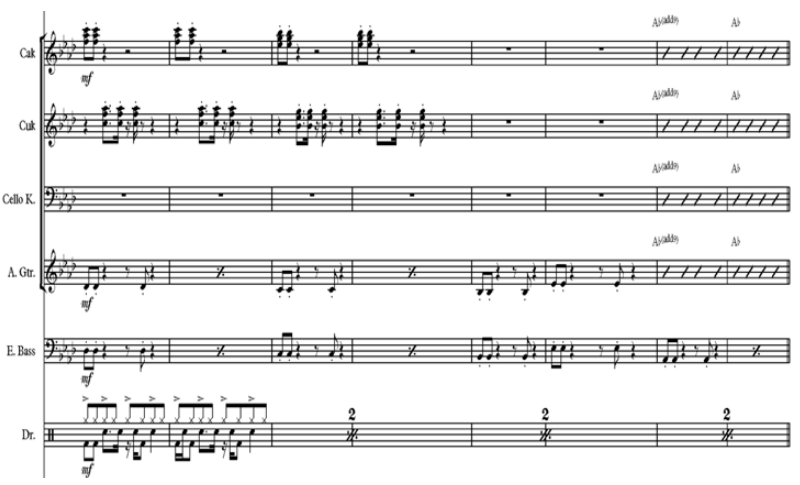

Notasi 9: Pola irama keroncong inovatif 3.

d. Penerapan Keroncong Inovatif yang Keempat Dimulai pada Komposisi Kidung Panyuwun di Huruf $F$

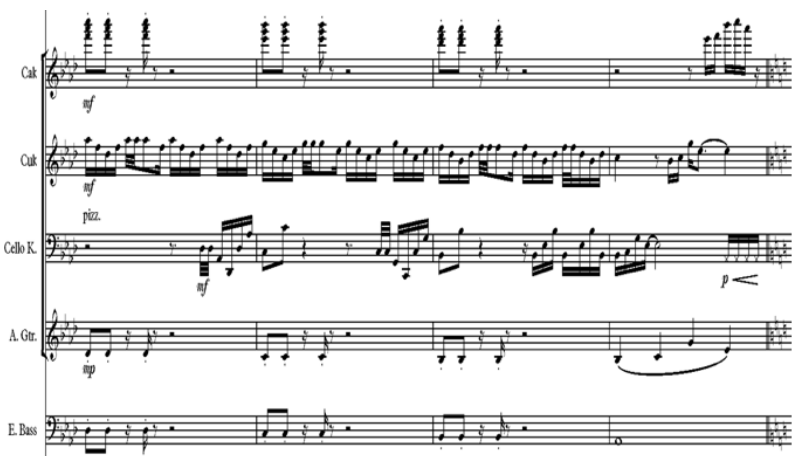

Notasi 10: Pola irama keroncong inovatif 4.

Konsep penggarapan pola irama keroncong inovatif 4 ini yang utama adalah menonjolkan instrumen keroncong. Instrumen keroncong bermain seperti pola irama engkel keroncong pakem (Notasi 11).

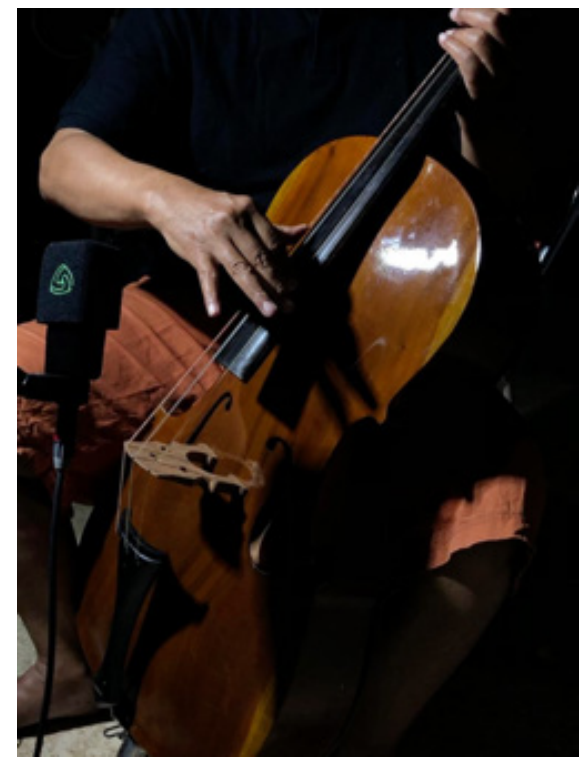

Gambar 1: Instrumen cello kendang bermain pola irama inovatif. 


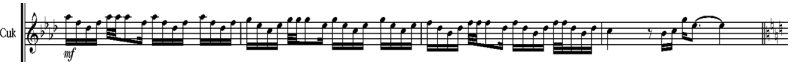

Notasi 11: Permainan instrumen keroncong dengan gaya pakem.

Inovasi pada garapan instrumen cello kendang ditulis dengan notasi seperti yang ada di Notasi 12. Cello kendang tidak bermain layaknya pada permainan engkel gaya pakem, tetapi ditulis nada pernada dan sejauh ini peneliti belum pernah menjumpai garapan yang demikian. Sepengetahuan penulis belum pernah menjumpai penggarapan seperti ini. Instrumen cak, akustik gitar, dan bass digarap dengan konsep 'uni-ritme'.

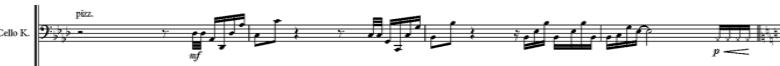

Notasi 12: Garapan inovatif instrumen cello kendang.

\section{Kesimpulan}

Penelitian ini telah menemukan ciptaanciptaan pola irama keroncong progresif dan menemukan beberapa formulasi penciptaan pola irama keroncong progresif. Beberapa formulasi yang ditemukan, yaitu penciptaan pola irama keroncong progresif vertikal (solo satu instrumen, solo dua instrumen, solo tiga instrumen) dan penciptaan pola irama keroncong progresif horizontal (pola satu, dua dan pola empat birama).

Sebuah temuan yang bermakna dalam penelitian ini adalah bahwa penulis menemukan 'jati diri' musik keroncong yang merupakan 'ruh musik keroncong' yaitu; gaya cuk yang sudah bercampur rasguardo dan trimolo yang ada kemiripannya dengan permainan 'kethuk' gamelan Jawa; gaya permainan cello yang mengadopsi permainan kendang gamelan Jawa; gaya permainan cak yang berfungsi sebagai 'peng-imbal' (counter atau kontra) permainan cuk. Gaya permainan flute yang dipengaruhi permainan 'suling' gamelan Jawa yang akhirnya menemukan 'gayanya sendiri'; dan gaya pembawaan vokal yang terinspirasi dari gaya bernyanyi 'sindhen' dalam karawitan Jawa.

Penelitian ini diharapkan supaya musik keroncong akan lebih menarik secara musikal sehingga lebih banyak peminatnya. Keberhasilan penelitian ini kiranya tidak dapat disimpulkan sekarang karena harus dibuktikan setelah hasil penciptaan pola keroncong progresif tersebut disosialisasikan dan perlu diadakan angket. Jadi penelitian ini harus dilanjutkan sampai pada fase tersebut.

Komposisi Kidung Panyuwun silakan dilihat di kanal Youtube: Singgih Sanjaya - Kidung Panyuwun (link: https://youtu.be/L-Fr0PQa1v0)

\section{Kepustakaan}

Alfian, M. (2013). Keroncong Music Reflects the Identity of Indonesia. Tawarikh-International Journal for Historical Studies, 4(2), 171-186. https://mindamas-journals.com/tawarikh/ article/view/555

Bramantyo, T. (2018). Early Acceptance of Western Music in Indonesia and Japan. Arts and Social Sciences Journal, 9(5). https:// astonjournals.com/manuscripts/Vol_9_2018/ ASSJ_Vol9_5_early-acceptance-of-westernmusic-in-indonesia-and-japan-2151-62001000408.pdf

Dallin, L. (1984). Techniques of Twentieth Century Composition - A Guide to the Materials of Modern Music, WM. C. Brown Company Publishers, California - USA.

Ganap, V. (2006). Pengaruh Portugis pada Musik Keroncong. Harmonia Journal of Arts Research and Education, 7(2). https://doi. org/10.15294/harmonia.v7i2.753

Hendry, Y. (2011). Musik Keroncong Campur Sari dalam Pluralitas Budaya Masyarakat Sawahlunto. Resital Jurnal Seni Pertunjukan, 12(1), 84-95. https://doi.org/10.24821/ resital.v12i1.468

Jayantoro, S. (2019). Tranformasi Konfrontatif Komposisi Gamelan Baru: Revitalisasi Penciptaan Inovatif dan Peran Vital Perguruan Tinggi Seni. Keteg: Jurnal Pengetahuan, Pemikiran, dan Kajian Tentang Bunyi, 18(1), 25-38. https://doi.org/ 10.33153/keteg.v18i1.2394

Kannan, S., Shaik Syed Ali, P., Sheeza, A., \& Hemalatha, K. (2020). COVID-19 (Novel Coronavirus 2019) - recent trends. European Review for Medical and Pharmacological 
Sciences. https://doi.org/10.26355/eurrev_ 202002_20378

Kristiana, N. N. D. (2015). Kajian Tekstual The Drupadi Trilogy Karya Ananda Sukarlan. Jurnal Kajian Seni, 2(1), 78-94. https://doi. org/10.22146/art.11651

Persichetti, V. (1961). Twentieth Century Harmony Creative Aspects and Practice. Faber And Faber Limited. London.

Prakosa, G. R., \& Haryono, S. (2012). Improvisasi Permainan Cello Pada Permainan Irama Jenis Langgam Jawa Grup Orkes Keroncong. Harmonia Journal of Arts Research and Education, 1(1), 68-76. https://doi.org/ 10.15294/jsm.v1i1.1802

Rachman, A. (2013). Bentuk Dan Analisis Musik Keroncong Tanah Airku Karya Kelly Puspito. Harmonia Journal of Arts Research and Education, 13(1), 69-77. https://doi. org/10.15294/harmonia.v13i1.2534

Rachman, A., \& Utomo, U. (2018). Sing Penting Keroncong. Jurnal Pendidikan dan Kajian Seni, 3(1), 47-63. http://dx.doi.org/10.30870/jpks. v3i1.4066

Ramadhani, F. A., \& Rachman, A. (2019). Resitensi Musik Keroncong di Era Disrupsi: Studi Kasus Pada O.K Gita Puspita di Kabupaten Tegal. Musikolastika: Jurnal Pertunjukan dan Pendidikan Musik, 1(1), 41-51. https://doi. org/10.24036/musikolastika.v1i1.18

Romadona, E. A. (2019). Penciptaan Musik Keroncong Dan Wayang Inovatif Dalam
Pertunjukan Congwayndut. Sorai: Jurnal Pengkajian Dan Penciptaan Musik, 12(1), 12-20. https://doi.org/10.33153/sorai.v12i1. 2619

Sanjaya, S. (2013). Metode Lima Langkah Aransemen Musik. Promusika: Jurnal Seni Pertunjukan, 1(1), 33-49. https://doi.org/ 10.24821/promusika.v0i0.538

Sanjaya, S. (2018). New Composition Concept for Keroncong Music in the Oboe Concerto with Keroncong and Orchestra. IJCAS, 5(2), 7585. https://doi.org/10.24821/ijcas.v5i2.2413 Soedarsono, R. M. (2001). Metode Penelitian Seni Pertunjukan dan Seni Rupa dengan Contohcontoh untuk Tesis dan Dosertasi. Bandung: Masyarakat Seni Pertunjukan Indonesia.

Suneko, A. (2016). Pyang Pyung: Sebuah Komposisi Karawitan. Resital Jurnal Seni Pertunjukan, 17(1), 60-66. https://doi.org/ 10.24821/resital.v17i1.1690

Tranquada, J., \& King, J. (2012). The 'Ukulele: A History. University of Hawa'I Press, Honolulu.

Widyanta, N. C. (2017). Efektifitas Keroncong Garapan Orkes Keroncong Tresnawara Terhadap Audiensi Generasi Muda. Jurnal Kajian Seni, 03(02), 165-180. https://doi. org/10.22146/jksks.30042

Zandra, R. A. (2019). Keroncong Gaya Keempat (Kajian Bentuk dan Gaya Penyajian). JADECS (Jurnal of Art, Design, Art Education \& Cultural Studies), 04(01), 39-47. http:// dx.doi.org/10.17977/um037v4i1p39-47 